\title{
Pelestarian Tari Andun pada Masyarakat Bengkulu Selatan
}

\section{and THEATREREVIEW}

jurnal tari, teater, dan wayang volume 3 number 2 ,

November 2020

page $72-81$

\author{
Sella Tri Komala ${ }^{1}$, Supriyanti, dan Rina Martiara \\ Jurusan Tari, Fakultas Seni Pertunjukan, Institut Seni Indonesia Yogyakarta
}

\begin{abstract}
Preservation of Andun Dance in South Bengkulu. Andun dance is one of the dances of South Bengkulu's people, which is currently less popular. This dance is a form of cultural and traditional art in South Bengkulu that still exists and has Islam and traditional nuance. In a marriage ceremony, for example, this dance is performed for seven days and seven nights. For those with a modern view, the Andun dance is a series of long and tiring processions and should be abandoned or modified. However, because it has become a custom and tradition, most people still carry out this long procession until now, even though it requires a lot of time and money. Andun dance is now less attractive because there are so many foreign cultures that enter South Bengkulu people, especially its young people. Andun dance is also getting worse because the places to express this dance are decreasing in number. For example, South Bengkulu people's traditional marriage rituals are usually held for seven days and seven nights. Still, at present, the practices held are not carried out that long. Andun dance, which is currently experiencing ups and downs, has not been able to regrow the community's interest and youth. This research focuses on how the efforts to preserve the Andun Dance in the people of South Bengkulu. One of the efforts made by the government is to carry out the Andun dance festival. In several leading schools, Andun dance is taught as extracurricular activities. The efforts made by the community regarding the preservation of the Andun dance are deliberating so that the Andun dance can be performed by the middle to lower class communities. Besides, artists also carry out preservation efforts by providing guidance or training for Andun dance to their students.
\end{abstract}

Keywords: preservation; Andun dance; South Bengkulu

\section{Pendahuluan}

Tari Andun adalah tari tradisional yang hidup, tumbuh, dan berkembang di tengahtengah masyarakat Bengkulu Selatan. Tari Andun dari dahulu sampai sekarang tidak diketahui siapa penciptanya dan tahun berapa pertama kali ditarikan. Masyarakat hanya mengatakan bahwa tari ini dari dahulu sudah ada. Tari Andun selalu ada pada setiap upacara perkawinan adat masyarakat Bengkulu Selatan. Tari Andun dahulu diselengarakan beserta upacara perkawinan adat yang diadakan selama tujuh hari tujuh malam selama Bimbang Adat (pesta pernikahan).

Berdasarkan legenda, tari Andun pertama kali ditampilkan saat pesta perkawinan Putri Bungsu Sungai Ngiang Pagar Ruyung dengan Dangku Rajau Mudau di Kerajaan Dang Tuanku Limau Serumpun dari daerah Bengkulu Selatan. Perayaan pesta perkawinan dengan menggunakan tarian merupakan wujud tanda syukur Dayang Remunai, ibunda Rajau Mudau, atas keselamatan Putri Bungsu yang sebelumnya diculik oleh Imam Jaya dari Kerajaan Sangkalawi. Atas perintah Dayang

$1 \quad$ Alamat korespondensi: Jurusan Tari, Fakultas Seni Pertunjukan, Institut Seni Indonesia Yogyakarta. Email: sella3komala@gmail.com; HP.: 081225259694. 
Remunai, Cindur Matau, kakak dari Rajau Mudau, diperintahkan untuk menyelamatkan Putri Bungsu dengan membawa si Benuang (seekor kerbau jantan) sebagai hadiah untuk Kerajaan Sangkalawi agar tidak ada kecurigaan dengan penyamarannya, dan membawa Si Gumarang (seekor kuda) sebagai tunggangan Cindur Matau. Setelah Putri Bungsu berhasil diselamatkan dan dibawa kembali oleh Cindur Matau ke Kerajaan Dang Tuanku Limau Serumpun, pernikahan antara Putri Bungsu dengan Rajau Mudau segera dilaksanakan selama tujuh hari tujuh malam yang disebut dengan Bimbang Adat (upacara perkawinan). Dalam proses Bimbang Adat, seluruh masyarakat menari sebagai ungkapan rasa kegembiraan dan syukur. Tari inilah yang disebut tari Andun.

Tari Andun dibedakan menjadi dua berdasarkan kelompok penari, yaitu tari Andun Kebanyakan dan tari Andun Lelawanan. Tari Andun Kebanyakan, yaitu tarian yang ditarikan secara beramai-ramai (berkelompok) dengan jumlah penari lebih dari sepuluh orang. Penari pada tari Andun Kebanyakan adalah dari kaum yang sejenis, misalnya kalau pengantin lakilaki yang menari maka semua pengikutnya atau rombongannya haruslah laki-laki semua, begitu juga sebaliknya. Setiap penyajian tari Andun Kebanyakan maka yang pertama tampil atau yang pertama kali melaksanakan tari adalah rombongan dari pihak laki- laki, dengan cara tujuh putaran ke kanan dan tujuh putaran ke arah kiri, lalu disusul rombongan pihak pengantin perempuan dengan cara yang sama. Sementara itu, personil pada tari Andun Kebanyakan terdiri dari berbagai kalangan, baik tua, muda, maupun anak-anak, semua ikut menari. Tari Andun Lelawanan ialah tarian yang dilakukan secara berlawanan atau berpasangan oleh laki-laki dan perempuan (bujang dan gadis) yang belum menikah atau yang belum berkeluarga. Tari Andum Lelawanan ditarikan oleh tiga pasang penari (tiga laki-laki dan tiga perempuan). Pada tari Andun cara lelawanan ini, yang memulai dan mengakhiri gerakan (yang memimpin) adalah lelaki, sementara perempuan hanya mengikuti dan meniru saja.

Tema dari tari Andun ini adalah penghormatan. Penghormatan yang dimaksud meliputi segala sesuatu yang berhubungan dengan rasa syukur kepada Tuhan Yang Maha Esa, rasa syukur dan hormat kepada orang tua, dan rasa syukur serta hormat kepada yang mendukung pelaksanaan acara tersebut.

Properti pada tari Andun berupa selendang atau kain songket panjang. Selendang digunakan pada gerakan yang terakhir, yaitu nyentang. Baik laki-laki maupun perempuan, melakukan gerak nyentang dengan menggunakan selendang yang diletakkan di bagian dada untuk perempuan dan di belakang pinggang untuk laki-laki.

Pelaku dalam tari Andun yaitu bujang, gadis, inang, serta pemusik. Bujang dan gadis yang dimaksud ialah perempuan dan laki-laki yang belum pernah menikah serta berkeluarga. Jumlah bujang dan gadis yang menari tidak dibatasi berapa pasang, hanya saja biasanya pada saat pertunjukan, ada tiga pasang bujang dan gadis yang menari, kemudian dilakukan bergantian sesuai dengan giliran yang ditetapkan oleh Inang. Inang ialah pendamping yang sudah dikategorikan sebagai dewasa, dalam hal ini orang yang mengerti adat dan sudah berkeluarga atau berumah tangga. Inang berfungsi sebagai orang yang bertugas mengatur kelancaran pelaksanaan tari Andun saat pelaksanaan Bimbang Adat. Selain itu, inang juga berfungsi sebagai penghimbau bujang gadis yang akan menari. Inang hanya diperbolehkan satu orang, boleh perempuan ataupun laki-laki. Pemusik, yaitu orang yang bertugas mengiringi tari, dalam hal ini yang memegang alat musik redap dan kelintang. Pemusik biasanya berjumlah tiga orang, dua orang menggunakan alat musik kelintang dan satu orang menggunakan alat musik redap (gendang). Fungsi musik tari Andun sebagai pengatur tempo. Tempo musik dari mulai tarian sampai akhir tarian tetap, tidak mengalami perubahan. Alat musik kelintang dibuat dari logam dengan alasan agar bunyi 
yang dihasilkan lebih lantang. Sementara itu, redap digunakan sebagai pengatur jalannya irama yang dipadukan dengan irama dari musik kelintang.

Tari Andun adalah bentuk kesenian tradisional yang memiliki nilai-nilai tradisional yang layak untuk dilestarikan. Sebagai kerja pelestarian, penting kiranya untuk mendeskripsikan sekaligus menganalisis bentuk tari Andun. Keberhasilan kerja pelestarian tergantung pada seberapa jauh pemerintah, seniman, dan masyarakat mengapresiasi keberadaan tari Andun melalui peraturan dan kebijakan pemerintah.

Tujuan penelitianadalah mendeskripsikan dan menganalisis pelestarian tari Andun dan nilai-nilai tradisionalnya, serta menganalisis kerja pemerintah, seniman, dan masyarakat pada saat mengapresiasi tari Andun. Penelitian ini menggunakan pendekatan sosiologi dan koreografi. Sumandiyo Hadi dalam bukunya, Sosiologi Tari: Sebuah Pengenalan Awal, (2007: 39) mengatakan bahwa keberadaan tari tidak akan pernah tuntas tanpa mengikutsertakan aspek-aspek sosiologisnya. Hal-hal tersebut berguna bagi peneliti untuk membantu permasalahan objek penelitian yang berkaitan dengan keberadaan tari dengan masyarakat pendukungnya. Pembahasan tentang fenomena yang ada dalam tari menjadi lebih menarik dengan menganalisis perubahan dan perkembangan yang terjadi dalam masyarakat.

Pendekatan sosiologi digunakan karena berhubungan dengan proses interaksi antara manusia dengan masyarakat. Dalam pelestarian tari Andun perlu dianalisis bagaimana proses interaksi pemerintah daerah dengan seniman, dan seniman dengan masyarakat pencinta seni. Untuk mengetahui hasil dari proses interaksi yang dilakukan maka pendekatan ini memerlukan sebuah konsep yang dijadikan acuan untuk memecahkan masalah. Konsep yang dimaksud berada dalam pendekatan koreografi, yaitu antara seniman dan pelestarian bentuk tari Andun.

Pendekatan koreografi ialah pendekatan dengan cara mengkaji objek penelitian dari sudut pandang koreografinya yang meliputi beberapa aspek, antara lain gerak tari, ruang dan waktu, properti yang digunakan, tata rias dan busana, serta iringan, sehingga pertunjukan tersebut menjadi satu kesatuan. Sebagaimana dijelaskan Y. Sumandiyo Hadi (2012: 15) dalam buku Koreografi BentukTeknik-Isi bahwa pendekatan koreografi merupakan sebuah pemahaman melihat atau mengamati sebuah tarian yang dapat dilakukan dengan menganalisis konsep-konsep isi, bentuk, dan tekniknya (content, form, and technique). Ketiga konsep ini sesungguhnya merupakan satu kesatuan dalam bentuk tari, namun dapat dipahami secara terpisah.

Metode penelitian merupakan cara yang digunakan untuk mendapatkan suatu hasil yang dapat dipertanggungjawabkan keberadaannya. Metode penelitian yang digunakan dalam penelitian ini ialah metode deskriptif analisis, yaitu mendeskripsikan objek secara tekstual, membuat analisis secara sistematis, faktual, dan mengemukakan data-data yang akurat dari objek. Penelitian kualitatif merupakan jenis penelitian yang temuan-temuannya tidak diperoleh melalui prosedur statistik atau hitungan lainnya. Prosedur ini menghasilkan temuan yang diperoleh dari data-data yang dikumpulkan dengan menggunakan beragam sarana. Sarana itu meliputi pengamatan dan wawancara, namun bisa juga mencangkup dokumen, buku, kaset, video. (Anselm Strauss dan Juliet Corbin: (2003: 4-5). Penggunaan metode ini supaya peneliti dapat menganalisis pokok permasalahan dalam objek penelitian.

Penelitian ini mengambil objek tari Andun. Objek penelitian berada di Bengkulu Selatan. Pemilihan lokasi penelitian didasarkan atas pertimbangan bahwa di Bengkulu Selatan tari Andun masih berlangsung baik sampai saat ini. Dalam penelitan, beberapa tahap penelitian harus dilakukan supaya mendapatkan hasil yang maksimal, yaitu teknik pengumpulan data dilakukan, baik lewat studi pustaka, observasi, wawancara, maupun dokumentasi. Penulis mengamati secara langsung pementasan 
tari Andun. Wawancara digunakan untuk menggali bahan-bahan atau informasi yang belum diketahui atau untuk memperkuat data. Pengumpulan data yang digunakan dalam penelitian ini, yaitu pada tahap studi pustaka, sumber data dikumpulkan dari buku-buku dengan cara mengkaji sumbersumber pustaka yang berkaitan dengan pokok permasalahan dari objek penelitian. Peneliti memperoleh beberapa sumber pustaka, di antaranya dari perpustakaan Institut Seni Indonesia Yogyakarta dan buku-buku milik pribadi, sesuai kebutuhan pustaka yang digunakan. Observasi dilakukan di Kabupaten Bengkulu Selatan. Observasi digunakan dalam rangka mengumpulkan data dalam suatu penelitian. Observasi dilakukan di Sanggar Tari Rentak Selatan, Bengkulu Selatan. Observasi dilakukan dengan mengamati beberapa kali pementasan yang dilakukan oleh Sanggar Tari Rentak Selatan, Bengkulu Selatan.

Wawancara merupakan sebuah dialog antara pewawancara dan narasumber untuk mendapatkan informasi tentang objek penelitian yang tidak bisa diamati oleh indera penglihatan. Metode wawancara ini mengadakan percakapan kepada para pelaku seni ataupun berbagai pihak yang mengetahui tentang tarian. Dalam wawancara berstuktur, sebelumnya sudah dirancang beberapa pertanyaan yang akan diajukan kepada narasumber untuk memperoleh jawaban dan keterangan yang jelas. (Nasution, 2004: 117) Narasumber dalam penelitian ini, yaitu Dali Yazid, seniman, pelatih Sanggar Rentak Selatan, Bengkulu Selatan (47 thn). Wawancara yang dilakukan dengan pelatih Sanggar Rentak Selatan berkaitan dengan data-data dan informasi tentang tari Andun tersebut. Narasumber lainnya ialah Densi Hartini, seorang PNS Pariwisata Manna, Bengkulu Selatan (40). Wawancara dengan narasumber dilakukan dengan tatap muka secara langsung dan melalui alat elektronik atau telepon seluler. Dokumentasi dilakukan dengan pemotretan yang menghasilkan fotofoto yang digunakan untuk mendeskripsikan objek yang diteliti. Selain itu, dokumentasi juga dilakukan dengan cara merekam objek menggunakan camera digital untuk memperjelas pengamatan dan pendeskripsian tari Andun. Analisis data merupakan suatu proses mencari dan menyusun data yang telah diperoleh dari observasi, wawancara, studi pustaka, dan dokumentasi. Tahapan analisis data dilakukan setelah seluruh data yang diperlukan lengkap terkumpul. Pada tahap ini data dikelompokkan terlebih dahulu, kemudian dianalisis dan dideskripsikan sampai penelitian berhasil disimpulkan, serta dapat menjawab permasalahan yang dirumuskan.

\section{Pelestarian Tari Andun pada Masyarakat Bengkulu Selatan}

Pelestarian berasal dari kata dasar lestari, yang artinya tetap selama-lamanya, tidak berubah. Istilah melestarikan mencakup, antara lain pengertian memelihara, menjaga, dan mempertahankan, serta membina dan mengembangkan. Melestarikan kebudayaan merupakan bentuk atau sikap mempertahankan nilai seni budaya ataupun nilai tradisi dengan upaya mengembangkan hasil kesenian yang ada. Sebuah kesenian yang bersifat dinamis dapat dikembangkan dengan situasi dan kondisi yang selalu berubah dan berkem-

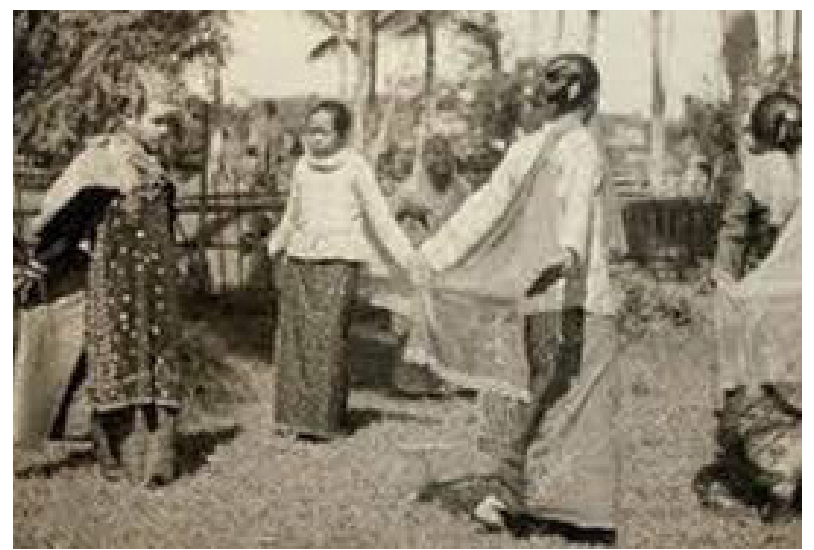

Gambar 1. Bentuk pertunjukan tari Andun di Bengkulu Selatan sebelum adanya program pelestarian. (Sumber: https://m.facebook.com/ SelumaIndonesia/photos/seni-budaya-kabupatenselumatari-andun-adalah-salah-satu-tarian-rakyatyang-bera/2135840109867684/) 
bang. Pelestarian merupakan sebuah upaya berdasar pada kemampuan yang dimiliki oleh pelaku budaya ataupun kesenian, dan dasar ini juga adalah faktor-faktor yang mendukungnya, baik itu dari dalam maupun dari hal yang dilestarikan. Melestarikan sebuah kebudayaan tentulah perlu adanya wujud budaya itu sendiri. Artinya bahwa budaya yang akan dilestarikan memang masih ada dan diketahui keberadaannya, walaupun dalam perkembangannya semakin terkikis atau dilupakan. Pelestarian hanya bisa dilakukan secara efektif manakala benda yang dilestarikan itu tetap digunakan dan dijalankan. Ketika budaya itu tidak digunakan kembali maka budaya itu akan hilang. Demikian pula ketika alat-alat kebudayaan tidak digunakan lagi oleh masyarakat, maka alat-alat itu hilang. Kebudayaan yang merupakan hasil dari karya manusia, tentulah menjadi tanggungjawab dan kewajiban manusia itu sendiri untuk terus menjaga dan melestarikannya.

\section{Nilai-Nilai dalam Tari Andun}

Nilai sebenarnya tidak ada ukuran yang pasti untuk menentukan. Nilai merupakan suatu hal yang dianggap baik atau buruk bagi kehidupan. Nilai merupakan sesuatu yang abstrak namun hal tersebut menjadi pedoman bagi kehidupan masyarakat. Adapun nilai sosial adalah penghargaan yang diberikan masyarakat kepada segala sesuatu yang terbukti memiliki daya guna fungsional bagi kehidupan bersama. Dengan demikian, nilai akan menjadi kaidah yang mengatur kepentingan hidup pribadi ataupun kepentingan hidup bersama sehingga nilai dapat dijadikan etika.

Tari Andun yang dimiliki oleh masyarakat Bengkulu Selatan merupakan suatu warisan budaya yang harus dilestarikan karena di dalam gerak tariannya mempunyai nilai-nilai agama, sosial, etika, dan estetika. Nilai agama (religi) bisa dilihat pada gerak sembah. Dalam gerak sembah terdapat nilai pnghormatan kepada Tuhan Yang Maha Esa dan kepada para leluhur. Pada gerak sembah juga terdapat nilai etika di dalamnya, yaitu kita sebagai sesama manusia, baik yang tua maupun yang muda, harus saling menghormati satu sama lain. Nilai sosial terkandung dalam gerak mbukak. Sikap keterbukaan yang harus dimiliki seseorang, yaitu terbuka untuk saling mengerti, terbuka untuk saling membantu, dan sesuai dengan sistem kekerabatan yang erat. Nilai sosial juga terdapat dalam gerak naup yang artinya merangkul ataupun menghimpun. Makna dari naup itu sendiri memiliki kaitan dengan sosial budaya masyarakat Bengkulu Selatan, yang memiliki kebiasaan untuk saling merangkul dalam kehidupan bermasyarakat. Makna gerak naup dalam tari Andun itu sendiri adalah ketika perempuan ataupun laki-laki memutuskan untuk menjalin kehidupan rumah tangga nantinya, keduanya siap menyimpan rahasia, bahkan aib, serta janji untuk kuat menghadapi apapun rintangan ke depan nantinya. Nilai etika terdapat dalam gerak nyentang karena memiliki nilai yang masih berhubungan dengan masalah perkawinan. Jika untuk perempuan, apabila sudah berumah tangga, biasanya hanya menerima apa saja yang diberikan oleh suaminya, sedangkan maksud untuk laki-laki adalah karena lakilaki merupakan pemimpin rumah tangga, jadi yang harus mengambil keputusan dengan bijak mengenai semua hal yang berhubungan dengan kehidupan dalam berumah tangga.

Selain memiliki nilai yang telah dijelaskan, tari Andun juga merupakan bentuk kesenian yang dibanggakan oleh masyarakat Kabupaten Bengkulu Selatan karena tari Andun hanya ada di Kabupaten Bengkulu Selatan. Kabupaten Bengkulu Selatan juga meemiliki ajang pemilihan putra dan putri daerah terbaik yang disebut Ajang Bujang dan Gadis. Ajang Bujang Gadis diselenggarakan setiap tahun, yang bertujuan untuk membuat anak muda lebih mencintai budayanya dan bangga terhadap kebudayaannya. Tujuan lainnya adalah untuk memperkenalkan budaya Kabupaten Bengkulu Selatan, terutama tari Andun ke masyarakat luas. Pemenang dari acara lomba 
Bujang dan Gadis Bengkulu Selatan nantinya menjadi contoh bagi anak muda lainnya, yaitu tidak hanya cantik dan ganteng, tetapi bujang dan gadis juga harus lebih mengetahui tentang adat dan budaya daerahnya. Ajang Pemilihan Bujang dan Gadis merupakan salah satu bentuk pelestarian tari Andun agar nantinya tarian tersebut dapat dinikmati dari generasi ke generasi. Agar nilai-nilai yang terkandung dalam tari Andun dapat terjaga dengan baik maka jalan satu-satunya adalah membenahi seni budaya yang dimiliki, memugarnya, menggali, dan mengembangkannya. Kemudian dalam jangka panjang secara terus-menerus dibina dengan cara pelatihan secara teratur.

\section{Upaya Pelestarian Tari Andun}

\section{Pemerintah}

\section{a. Festival}

Festival dari kata Latin, festum, yang berarti pesta, biasanya merupakan perayaan khusus yang diselenggarakan secara periodik, yakni sekali dalam satu tahun. Festival dapat diadakan pada berbagai peristiwa, seperti penghormatan, perayaan keagamaan, perayaan panen, awal suatu musim, dan perayaan peristiwa sejarah. Kebanyakan festival menggambarkan saat-saat bergembira, tetapi ada juga yang menggambarkan suasana berkabung dan bertobat. Festival juga diselenggarakan untuk merayakan peristiwa penting dalam suatu negara, misalnya memperingati hari jadi negara. Di Indonesia, festival utama adalah perayaan Hari Kemerdekaan yang jatuh pada tanggal 17 Agustus. Pesta perayaan tersebut dirayakan oleh seluruh rakyat Indonesia untuk mengenang detik-detik Proklamasi.

Upaya pelestarian tari Andun juga dilakukan di sekolah, yaitu dengan cara mengajarkan tari Andun kepada siswa siswi Sekolah Menengah Pertama (SMP) dan Sekolah Menengah Atas (SMA) atas inisiatif dari masing-masing sekolah yang membuat tari Andun menjadi kegiatan ekstrakurikuler di sekolah tersebut. Salah satu contohnya adalah SMAN 1 Manna, Bengkulu Selatan. Kegiatan ekstrakurikuler tari Andun di sekolah tersebut menggunakan metode pengajaran dan penjelasan, yang diikuti dengan mendemonstrasikan gerak tarinya. Dalam hal ini demonstrasi dilakukan secara langsung, yakni dengan mengajarkan susunan gerak tari Andun. ${ }^{2}$

Upaya pemerintah tidak hanya mengadakan lomba-lomba, tetapi pemerintahsaatinisedangmengupayakan untuk mewajibkan pejabat daerah melaksanakan upacara Bimbang Adat
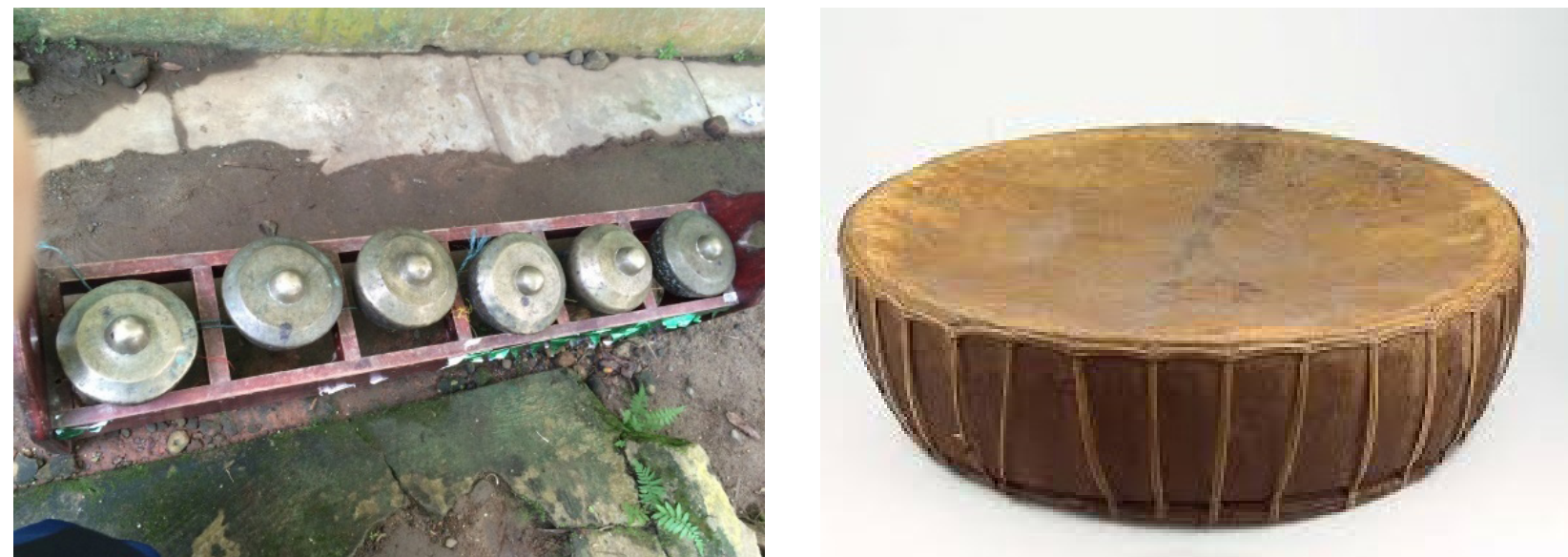

Gambar 2. Alat Musik Kelintang dan Redap. (Sumber: Sella, 15 Oktober 2016)

2 Wawancara dengan Densi Hartini, Guru Tari di Sekolah Menengah Atas (SMA), pada tanggal 12 Oktober 2016, diizinkan untuk mengutip. 
bagi mereka yang akan menikahkan anaknya. Hal tersebut dirasa tepat karena pejabat daerah dianggap mampu untuk melaksanakan Bimbang Adat. Tujuannya adalah untuk melestarikan kebudayaan upacara Bimbang Adat yang di dalam rangkaian upacaranya terdapat tari Andun, yang saat ini hampir hilang karena kemajuan teknologi. Dalam hal ini pemerintah harus menjadi contoh bagi masyarakatnya karena jika tidak dimulai dari pemimpinnya, siapa lagi yang akan menjadi panutan bagi masyarakat. Hal itulah yang membuat pemerintah berpikir bahwa usaha tersebut harus dimulai dari pemerintah/pejabat daerah itu sendiri. ${ }^{3}$

Kendala-kendala yang terdapat pada pendidikan formal adalah adanya siswa yang tidak berbakat. Siswa yang tidak berbakat sangat lamban dalam menerima materi praktik tari daripada siswa yang berbakat. Siswa yang tidak berbakat seringkali tidak bisa menari dengan baik. Hal demikian biasanya relatif terjadi pada siswa laki-laki, ditambah lagi dalam gerakan tari Andun sangat membosankan dan dilakukan berulangulang. Biasanya akan timbul kebosanan dan kejenuhan terhadap siswa yang tidak berbakat menari.

b. Pagelaran (Pertunjukan)

Pagelaran adalah suatu kegiatan dalam pertunjukan hasil karya seni kepada orang banyak pada tempat tertentu. Untuk mencapai suatu tujuan pada dasarnya pergelaran merupakan kegiatan konsumsi secara tidak langsung antara pemain dan penonton untuk mencapai kepuasan masing-masing (baik penonton maupun pemain). ${ }^{4}$ Pergelaran dalam $K B B I$ adalah pertunjukan (drama, wayang, orang, dan sebagainya). ${ }^{5}$

Pariwisata merupakan aset paling penting untuk memperkenalkan kebudayaan. Untuk itulah pemeritah berupaya agar tari Andun mempunyai peran penting di dalamnya. Selain dapat menjaga kelestariannya, juga dapat memperkenalkan tari Andun dalam pariwisata melalui pengisian acara-acara penyambutan tamu-tamu, pengisian acara-acara reuni, dan tidak jarang juga dikirim sebagai duta seni untuk mengisi pergelaran acara tari Nusantara di Jakarta, yang bertujuan untuk memperkenalkan kebudayaan masing-masing daerah di Taman Mini Indonesia Indah. Dengan demikian, pariwisata sangat penting dalam mengembangkan informasi lebih lanjut tentang tari Andun.

Usaha yang dilakukan Dinas Pariwisata adalah dengan cara mempertunjukkan tari Andun di Taman Mini Indonesia Indah (TMII). Dalam pertunjukan di TMII, tari Andun dikemas dengan waktu satu jam, bertemakan cerita asal usul tari Andun, yang dikemas secara menarik. Dari segi kostum, kostum penarinya dibuat lebih menarik

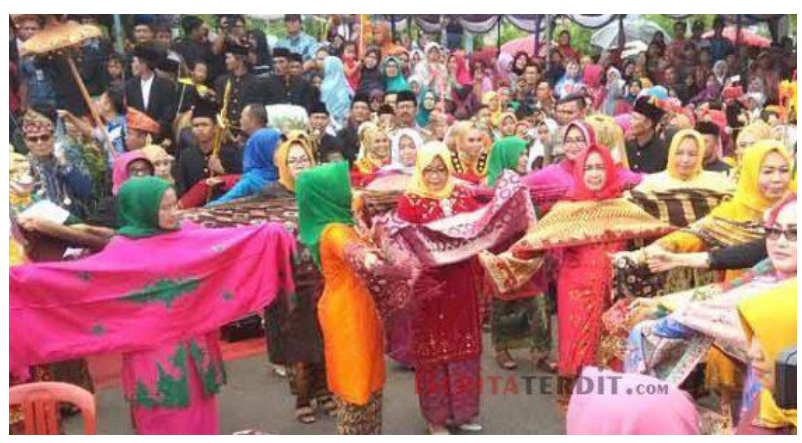

Gambar 3. Tari Andun saat acara Melemang Tapai HUT Kabupaten Bengkulu Selatan. (Sumber: http:// www.beritaterbit.com/hut-ke-69-bengkulu-selatandimeriahkan-acara-melemang-tapai)

\footnotetext{
Wawancara dengan Drs. H. Yulian fauzi sebagai Dinas Pariwisata, Kabupaten Bengkulu Selatan, pada tanggal 11 Oktober 2016, diizinkan untuk mengutip.

4 https://treeyoo.wordpress.com/2009/01/16/pergelaran/, diakses pada tanggal 10 Desember 2016.

5 http://kbbi.web.id/gelar-2 KBBI Online ini dikembangkan oleh Ebta Setiawan @2012-2016 versi 1,9. Database utama merupakan Hak Cipta Badan Pengembangan dan Pembinaan Bahasa, Kemdikbud (Pusat Bahasa), diakses pada tanggal 27 Oktober 2016.
} 
dan mewah. Saat dipertunjukkan di TMII, bentuk penyajian tari Andun tidak sama dengan pertunjukan aslinya yang biasanya dilaksanakan di tanah lapang. Musik iringannya pun lebih menarik dengan yang biasanya memakai kelintang dan redap. Saat dipentaskan di TMII, musik iringannya ditambah dengan DOL, Tasa, akordion, serunai, biola, dan biola klasik. Riasan dan busana dalam pementasan pun dibuat sangat menarik, dengan ditambahkannya aksesoris di bagian kepala, seperti sunting, di bagian baju ditambahkan payet yang berwarna kuning keemasan. Pilihan warna baju dipilih warna yang menyala, seperti kuning emas, biru terang, merah darah, hijau stabilo, dan oranye.

Ada kendala yang sering terjadi pada beberapa pelaku tari, yaitu penari menarikan tari Andun asal saja tanpa mengetahui makna yang terdapat dalam gerakannya. Saat tahap seleksi, tidak semua penari memahami makna dari tari Andun karena pada tahap penyeleksian tidak semua penari berasal dari Sanggar Rentak Selatan. Kebijakan Dinas Pariwisata meminta semua sanggar di Kabupaten Bengkulu Selatan ikut serta dalam pementasan di TMI, dengan syarat penyeleksian dari setiap sanggar.

2. Masyarakat (Musyawarah)

Upaya yang dilakukan masyarakat dengan cara menyampaikan kepada Badan Musyawarah Adat (BMA) tentang

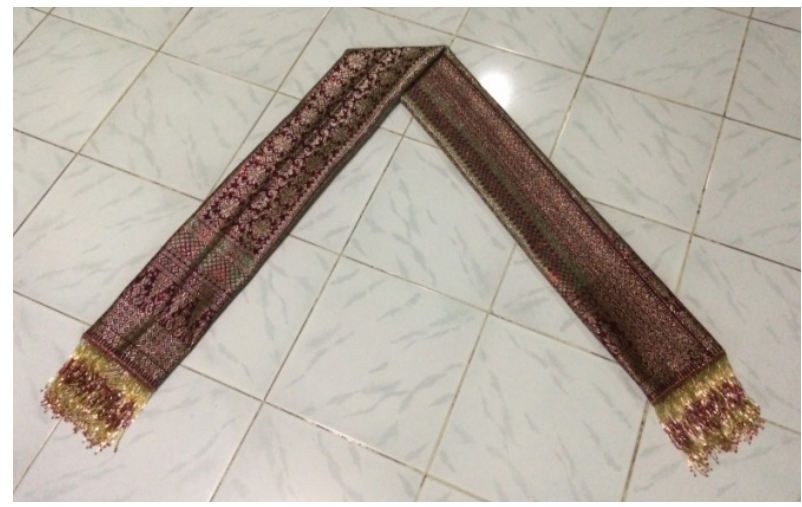

Gambar 4. Selendang sebagai properti tari Andun. (Sumber: Sella, 16 Oktober 2016) permasalahan Bimbang Adat karena Bimbang Adat tersebut membutuhkan biaya yang tidak sedikit, sedang dalam hati kecil masyarakat yang peduli akan kebudayaan menginginkan agar upacara Bimbang Adat tidak hilang/punah karena kemajuan teknologi yang semakin berkembang pesat. Masyarakat berharap ada upaya ataupun solusi dari pemerintah daerah agar Bimbang Adat (tari Andun) bisa dilakukan dengan biaya yang minimal. Masyarakat juga berusaha untuk melestarikan tari Andun dengan cara tetap mementaskan tari Andun dalam acara pernikahan yang saat ini hanya dilakukan dalam waktu tiga hari dua malam. Hal tersebut ditujukan agar tari Andun bisa dinikmati oleh masyarakat dan generasi-generasi muda yang akan datang. Dikarenakan waktu pertunjukan yang singkat maka ada banyak properti atau atribut yang hilang karena kendala biaya dan waktu. Akan tetapi, masyarakat dengan kemampuan yang mereka miliki, berusaha untuk tetap menampilkan tari Andun di hadapan masyarakat sekitar dan sanak saudara yang hadir.

3. Seniman (Sanggar Rentak Selatan/SRS)

Sanggar Rentak Selatan memiliki jadwal yang pasti untuk latihan, yaitu pada hari Jumat, sedangkan sanggar yang lain mengadakan latihan bila ada pementasan saja. Upaya yang dilakukan oleh Sanggar Rentak Selatan tersebut bertujuan untuk melancarkan proses pembelajaran yang ada di sanggar. Sanggar Rentak Selatan

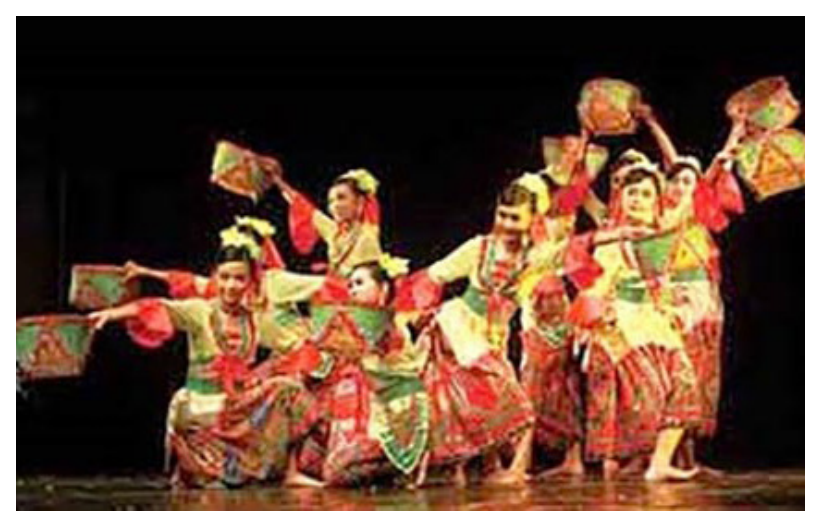

Gambar 5. Pelestarian tari Andun. (Sumber: tintapendidikanIndonesia.com) 
melakukan upaya-upaya pembinaan dan pelestarian kepada anak didik dalam bidang kesenian, terutama seni tari.

Pembinaan seni tari yang dilakukan oleh sanggar bertujuan agar tercipta kelancaran proses kegiatan pembelajaran tari, baik di dalam sanggar maupun di luar sanggar. Oleh karena itu, Sanggar Rentak Selatan memberikan peluang untuk masyarakat yang suka berkesenian dapat bergabung dalam latihan tari. Upaya pembinaan dan pelestarian yang dilakukan oleh sanggar merupakan upaya untuk menunaikan hak dan kewajibannya dalam melestarikan tari Andun agar tidak punah dan dapat lestari dalam masyarakat, baik lingkungan sanggar maupun luar sanggar. Hal itu dilakukan dengan cara memberikan materi tari, baik tari Andun maupun tari kreasi baru, kepada peserta didik yang ingin mengetahui dan memahami tari yang ada di Manna, Bengkulu Selatan.

Tidak semua yang manusia inginkan dapat terwujud dalam sekejap. Keinginan tersebut dapat diraih dengan berusaha sebaik dan sekuat mungkin agar apa yang diinginkan dan dicita-citakan dapat segera terwujud. Wujud dari yang diinginkan terkadang tidak sesuai dengan apa yang dibayangkan. Hal tersebut wajar karena apa yang kita usahakan terkadang tidak sebanding dengan apa yang kita dapat. Begitu juga usaha yang dilakukan oleh pemerintah, masyarakat, dan seniman dalam pelestarian tari Andun, tidak semua yang diusahakan akan berhasil dengan baik. Usaha-usaha yang telah dilakukan akan dianggap berhasil jika peminat terhadap tari Andun semakin banyak, baik dari kalangan pelajar, anggota sanggar, maupun masyarakat luas. Keuletan yang dilakukan oleh pemerintah, masyarakat, dan seniman diharapkan akan membawa hasil seperti yang dicita-citakan.

Hasil dari berbagai upaya yang dilakukan pemerintah, masyarakat, dan seniman sampai saat ini masih dalam proses, dan hasilnya sedikit banyak sudah terlihat dari mulai diadakannya lagi upacara Bimbang Adat yang di dalamnya terdapat tari Andun. Hal itulah tujuan utama diadakannya program-program pelestarian kebudayaan di daerah Bengkulu Selatan. Masyarakat pun merespon dengan baik programprogram yang dilakukan pemerintah sehingga pemerintah tidak harus bersusah payah memberikan pengarahan tentang pentingnya pelestarian kebudayaan daerah Bengkulu Selatan, terutama tari Andun. Pemerintah juga memberi kemudahan bagi masyarakat menengah ke bawah agar bisa melaksanakan upacara Bimbang Adat. Bagi masyarakat menengah ke bawah, tidak perlu melakukan rangkaian upacara Bimbang Adat secara utuh, tetapi tari Andun wajib ada pada rangkaian acara tersebut. Meskipun demikian, hal tersebut tidak mengurangi makna dari upacara Bimbang Adat yang sebenarnya.

\section{Penutup}

Tari Andun merupakan tarian yang hanya terdapat di Provinsi Bengkulu, tepatnya di Kabupaten Bengkulu Selatan. Tari Andun dari dahulu sampai sekarang tidak diketahui siapa penciptanya dan tahun berapa tari ini pertama kali ditarikan. Masyarakat hanya mengatakan bahwa tari ini dari dahulu sudah ada. Tari Andun selalu ada pada setiap upacara perkawinan adat masyarakat Bengkulu Selatan. Tari ini dahulu diselenggarakan beserta upacara perkawinan adat yang diadakan selama tujuh hari tujuh malam, yang dikenal sebagai upacara Bimbang Adat (pesta pernikahan). Pengertian bimbang yang dimaksudkan sebenarnya adalah ragu-ragu atau takut, berani atau tidak, dan untuk orang yang akan melaksanakan acara pernikahan anaknya, mempunyai rasa ragu-ragu apakah kegiatan upacara perkawinan itu dapat terlaksana dengan baik atau tidak. Begitu pula dengan perasaan pengantin, apakah di dalam hidup berumah tangga nantinya berjalan dengan baik dan harmonis atau tidak. 
Upaya pelestarian tari Andun yang dilakukan oleh pemerintah adalah menyelenggarakan lomba-lomba, dan menjadikan tari Andun sebagai kegiatan ekstrakurikuler di sekolah tingkat SMP dan SMA. Pemerintah juga mengupayakan kebijakan untuk pejabat-pejabat daerah berupa kewajiban melaksanakan upacara Bimbang Adat bagi anak mereka yang akan menikah. Hal tersebut dirasa tepat karena pejabat daerah mampu untuk melaksanakan Bimbang Adat. Tidak hanya pemerintah, masyarakat pun turut andil dalam upaya pelestarian tari Andun, yaitu dengan mengikuti aturan yang dibuat pemerintah. Aturan tersebut memberi kemudahan berupa toleransi waktu upacara Bimbang Adat, yakni yang semula dilakukan selama tujuh hari tujuh malam, menjadi tiga hari dua malam bagi masyarakat menegah ke bawah. Kebijakan pemerintah itu tidak mengurangi makna dari acara tersebut. Seniman pun turut andil dalam pelestarian tari Andun, yakni dengan membuka sanggar tari. Sangar tari yang ada di Bengkulu Selatan berjumlah enam sanggar. Sanggar Rentak Selaran adalah salah satu sanggar yang anak didiknya setiap tahun semakin bertambah, serta sering berpartisipasi dalam acara-acara di dalam ataupun di luar Kabupaten Bengkulu Selatan.

\section{Kepustakaan}

Hadi, Y. Sumandyo. 2007. Sosiologi Tari: Sebuah Pengenalan Awal, Yogyakarta: Penerbit Pustaka.

Hadi, Y. Sumandyo. 2012. Koreografi BentukTeknik-Isi, Yogyakarta: Cipta Media

Kussudiardjo, Bagong. 1993. Olah Seni Sebuah Pengalaman. Yogyakarta: Bentang Intervisi Utama.

Nasution, S. 2004. Metode Research: Penelitian Ilmiah, Jakarta: Bumi Aksara

Poerwanto, Hari. 2000. Kebudayaan dan Lingkungan dalam Perspektif Antropologi. Yogyakarta: Pustaka Pelajar.
Sedyawati, Edi. 1981. Pertumbuhan Seni Pertunjukan. Jakarta: Sinar Harapan.

Sedyawati, Edi. 1984. Tari Tinjauan dari Berbagai Seni. Jakarta: Dunia Pustaka.

Sedyawati, Edi. 1986. Pengetahuan Elementer Tari dan Beberapa Masalah Tari. Jakarta: Proyek Pengembangan Kesenian Jakarta, Depdikbud.

Soedarsono. 1996. Indonesia Indah : Tari Tradisional Indonesia. Jakarta: Yayasan Harapan Kita.

Soedarsono, R.M. 1999. Seni Pertunjukan dan Pariwisata. Yogyakarata: BP ISI Yogyakarta.

Soedarsono, R.M. 2008. Sekelumit Ruang Pentas Modern dan Tradisi. Yogyakarta: Cipta Media.

Soedarsono, R.M. 2003. Seni Pertunjukan dari Perspektif Politik, Sosial, dan Ekonomi. Yogyakarta: Gadjah Mada Universty Press.

Strauss, Anselm dan Juliet Corbin. 2003. Dasardasar Penelitian Kualitatif Tatalangkah dan Teknik-Teknik Teoritis Data, Terj. Muhammad Shodiq dan Imam Muttaqien, Yogyakarta: Pustaka Pelajar.

Sumaryono. 2007. Jejak dan Problematika Seni Pertunjukan Kita. Yogyakarta: Prasista.

Sumaryono. 2011. Antropologi Tari dalam Perspektif Indonesia. Yogyakarta: Badan Penerbit ISI Yogyakarta.

\section{Internet}

http://kbbi.web.id/lestari diakses pada tanggal 27 Oktober 2016, pukul 10.30 WIB.

http://kbbi.web.id/gelar-2 KBBI Online ini dikembangkan oleh Ebta Setiawan @2012-2016 versi 1,9. Database utama merupakan Hak Cipta Badan Pengembangan dan Pembinaan Bahasa, Kemdikbud (Pusat Bahasa), diakses pada tanggal 27 Oktober 2016.

http://google.pelestarian.budaya, diakases pada tanggal 27 Oktober 2016, pukul 11.17 WIB. 